\title{
Bankruptcy Prediction: A Model Based on Cash Flow Ratios: Evidence From Selected European Countries
}

\author{
Lorenzo Rizzo $^{1}$, Giorgio Valentinuz ${ }^{2}$, Dario Obratil ${ }^{3} \&$ Valentino Pediroda ${ }^{4}$ \\ ${ }^{1}$ modefinance SRL, Trieste, Italy \\ ${ }^{2}$ DEAMS, University of Trieste, Trieste, Italy \\ ${ }^{3}$ Generali Investments Assets Management, Trieste, Italy \\ ${ }^{4}$ DIA, University of Trieste, Trieste, Italy \\ Correspondence: Giorgio Valentinuz, DEAMS, University of Trieste, Trieste, Italy. Tel: 39-40-558-7917.
}

Received: October 11, 2020

Accepted: November 24, 2020

Online Published: November 29, 2020

doi:10.5430/ijba.v11n6p89

URL: https://doi.org/10.5430/ijba.v11n6p89

\begin{abstract}
The importance of assessing the financial distress risk of a company is a topic that has been of central value in many different economic fields and since a long time. Until the twenty-first century, most of the studies were concentrated primarily on using mathematical and statistical methods to assess the health of businesses. Many of these studies employed either accounting-based ratios or cash flow-based ratios; even if there is not a unique conclusion, the use of cash flows seems to improve the predictive capacity of the models significantly. Especially in the last twenty-five years, methods derived from different fields started to be applied in forecasting corporate failures, such as artificial neural networks, genetic algorithms, and fuzzy logic.

The objective of this study was to test the goodness of the discriminatory power of ratios based only on cash flows using a model that employs genetic algorithms and fuzzy logic. Five countries (Germany, Spain, France, Great Britain, Italy) and five Nace macro sectors (Agriculture, Industry, Services, Construction, Commerce and Food) have been considered in the analysis for a total of around 719-thousand companies. The model has proven to be well-performing on most of the countries and sectors that have been tested. The results obtained are almost all adequate; in particular, in Germany and Spain, results have been particularly good.

The main weaknesses of this work are the limited availability of financial data in some countries and the time delay from the reporting of financial statement to the availability of the data through web services. It means that a large-scale risk assessment requires - being useful for the public and the private sectors - greater and faster disclosure of information at European level, and standardization of financial information transparency among countries.
\end{abstract}

Keywords: bankruptcy prediction, credit scoring, cash flow ratios, fuzzy logic, genetic algorithms, selected European countries

\section{Introduction}

The lending of money works well in case of trust between parties, or when collateral is used or in case the information asymmetry is reduced. Knowing the financial health or constraints of a business is relevant not only for financial institutions (e.g. banks and factor companies), but also for suppliers of goods, industrial/commercial enterprises and for any entity that uses accounts payable or notes payable. Nowadays, because of COVID-19 and its economic effects on enterprises, the prediction of the insolvency risk has become really popular; but one of the most famous and earlier study how to predict a businesses' bankruptcy using financial ratios is owed to Altman's (1968). After this milestone, many studies were conducted using financial ratios to forecast corporate failure. In literature there is wide number of researches on the open question whether to use accrual accounting ratios or cash flow ratios as better financial distress predictors, and a common ground is not still achieved. Cash flows are become more strictly and homogeneously measured among different businesses, and newer methods and measures have made their appearance from other fields. Machine learning, artificial intelligence and optimization algorithms are not a new topic, but their use in the economic field, and in particular in the bankruptcy prediction, is making its way mostly in recent years. The development of new technologies and the introduction of powerful computers marked the 
beginning of using algorithms like support vector machines (SVM), decision trees, neural networks, and genetic optimization algorithms (GA) in this quest.

\subsection{The Importance of Cash Flows in Predicting Failure}

"Cash is King" is an extremely popular statement in finance, also because cash is the main mean of paying off creditors; but, as Sharma (2001) described, until that moment literature did not seem to have found a final conviction in favor of financial ratios based on cash flows in predicting bankruptcy. Beaver (1966) used a proxy of the operating cash flow (OCF) as the result of net income plus depreciation and amortization. The critique made to his study was mainly the adoption of a univariate technique for the financial analysis, unable to provide a clear signal in case the ratios were in conflict. Altman (1968) was able to demonstrate the ability of multiple discriminant analysis (MDA) in predicting bankruptcy, but he employed accrual accounting measures only, and no cash flows-based instruments. Almamya, Astona \& Ngwa (2015) extended the original Z-score model developed by Altman (1968), adding a new variable (Cash Flow from operations/total liabilities); they found that the extended model (called J-UK) is more accurate in predicting failed and non-failed general UK companies before, during and after the financial crisis period. Deakin (1972), Blum (1974), Norton \& Smith (1979), Mensah (1983) included the cash flow's definition of Beaver (1966) in their studies; and they were able to demonstrate the significance of cash flow in predicting corporate bankruptcy. Largay III \& Stickney (1980) as well as Gombola \& Ketz (1983) refined the definition of OCF proposed by Beaver (1966) by considering also changes in current assets and current liabilities, providing a more precise measure of cash flow. Casey \& Bartczak (1984) used 60 bankrupt and 230 non-bankrupt businesses, performing a univariate analysis employing six accrual ratios and three cash flow ratios. Both groups of ratios appear to be significant, but the cash flow ratios were not able to considerably increase the predictive ability of the model, although they both were able to predict bankruptcy, singularly. The same authors (Casey \& Bartczak, 1985) performed multiple discriminant analysis (MDA) and logit instead of univariate analysis, concluding that cash flow ratios were actually able to increase significantly the predictive ability of the accrual ones when used in combination. Gentry, Newbold, \& Whitford (1985) reinforced Casey \& Bartczak's (1985) findings by adding cash flow variables to an accrual model improving its precision significantly, but they used a different definition of cash flow that refers to Helfert (1972). Jones (2016) employed four cash flow based measures from listed companies - a) operating cash flow to total assets; b) net operating cash flow divided by interest payments, c) net operating cash flow divided by EBIT, and d) cash plus short-term investments over total assets - and a binary logistic regression to model failure. He concluded that the proposed model produces very good out-of-sample predictive accuracy with an AUC of around .85 .

A critique to operating cash flows (OCF) was moved by Viscione (1985): given the absence of a standard definition on OCF, its calculation could be manipulated by management to increase measures of cash flow, by - for example not paying accounts payable, invalidating its significance. In the opinion of the Authors, on the other hand, and even with more degree of freedom, the same can be done using accrual accounting measures. Also, by taking account of inventories and levels of financial debts, it is possible to overcome the weak spot in using cash flows. With their work, Gahlon \& Vigeland (1988) were able to create a cash flow model capable to assess corporate failure five years in advance. Dambolena \& Shulman (1988) improved the model of Gentry, Newbold, \& Whitford (1985) and Altman's model (1968) using net liquid balance ("the difference between all liquid financial assets (essentially cash and marketable securities) and all callable liabilities (essentially short-term notes payable and current maturity due on long-term debt"). Aziz \& Lawson (1989) compared their cash flow model to Altman Zeta model, demonstrating it was more accurate in predicting business failure. Gilbert, Menon, \& Schwartz (1990) demonstrated that adding cash flow variables improved prediction in accrual models significantly. Jooste (2007) provided additional evidence that cash flows presented directly in the cash flow statement of a company can be used to create predictive ratios. Bellovary, Giacomino, \& Akers (2007) did a review of bankruptcy prediction studies from 1930 to 2005; another interesting literature review towards forecasting models for default risk since the 1960s is due to Bisogno, Restaino \& Di Carlo (2018). Some further recent studies refer to Bhandari \& Johnson-Syder (2018) and Veronica, Ida, \& Winata (2020).

There is evidence that cash flows are better than accrual indicators in predicting business failure, even if there is no cohesion in what method is better. Sharma (2001) concluded that most of the differences are consequent of the non-homogeneous nature of the sample studied. The differences in terms of sectors, sizes, countries, and cash flow definitions used in the different studies do not permit to consider them strictly comparable. Nevertheless, the use of cash flows appears to significantly improve the predictive ability of many models in detecting possible business failure, and also theoretically it does make sense to build a model based on cash flow ratios to predict business default and test its effectiveness. 


\subsection{Methods Derived From Different Fields Used to Predict Bankruptcy}

The studies in the biology field, with the need to understand how biological organism work and evolve, were the pioneer in applying neural networks and genetic algorithms (GA). The latter were first time proposed by Holland (1975) to explain the adaptive process of chromosomes. The base idea behind the GA was the Darwinian evolutionary theory. A population of individuals that best fit certain characteristics, will have an evolutionary advantage over the others, and generation after generation will transmit their genes, containing these characteristics, to the future generations. Repeating the process generation after generation, only a population with characteristics that best fit the environment will remain. Even though this algorithm was born inspired by human evolution, it was used in many different fields. From immunology research to find out the development of certain diseases, in engineering with application on material engineering, to finance, often in conjunction with fuzzy logic or neural networks.

Artificial neural networks (ANN) have probably been the most widely used method of assessing financial distress in modern literature (Gorzalczany \& Rudzinski, 2016): they are able to find patterns in huge datasets, characteristic that fits well with the complex financial problems, that can otherwise be greatly oversimplified using a mathematical function. They work similarly as the human brain: as a matter of fact, artificial neural network where developed initially to study the behavior and functioning of the human brain and its underling neurons (McCulloch \& Pitts, 1943). Neural networks require to handle great amount of data but, thanks the develop of IT, they have proven to be very precise and reliable.

In literature there is not much evidence of using a model composed of solely cash flow ratios, but different studies have used financial ratios (both cash and accruals) with modern techniques to predict bankruptcy showing promising results. For example, support vector machines (SVMs) were used by Min \& Lee (2005), Shin, Lee, \& Kim (2005) and Lee (2007) to assess corporate credit rating; Moscatelli, Parlapiano, Narizzano \& Viggiano (2020) used machine learning techniques applied to a mix of accrual and cash flow ratios that provided a more accurate forecasting performance compared to statistical models, both in terms of discriminatory power and precision. The decision tree classification algorithm also made its appearance as a classification tool. It is a tree-structured classifier, like the ones used in operation research or operations management, but in this case run by a supervised machine learning algorithm and a Gini index it is used for optimization. In a decision tree classifier, the nodes represent the features of the dataset, the branches the rules and the leaves the outcomes of the classification task. Although decision trees incur in some limitations, given mostly by the long training time, the great dependency on the training set and the sensitivity to noise, some of them have been overcome by the use of ensembles (bagged and boosted decision trees) like the one of Sun, Jia, \& Li (2011) and Zięba, Tomczak, \& Tomczak (2016) or hybrid system like the one of Sun \& $\mathrm{Li}$ (2008). The use of ANN was widely implemented also prior 2000 as described in Bellovary, Giacomino, \& Akers (2007). The articles of Tam \& Kiang (1992), Wilson \& Sharda (1994), Yang, Platt, \& Platt (1999), Atiya (2001), Khashman (2009) are examples of studies of artificial neural networks applied to bankruptcy estimates, providing good accuracy prediction. Hybrid and ensemble ANN were also used, with even better results. The works of West, Dellana, \& Qian (2005), Tsai \& Wu (2008), Nanni \& Lumini (2009), Kim \& Kang (2010) are examples of ensemble ANN used in bankruptcy prediction. Hybrid artificial neural networks were also used in conjunction either with fuzzy logic (Vlachos \& Tolias, 2003) or with genetic algorithms, like in Back, Laitinen, \& Sere (1996), Back, Laitinen, Sere, \& van Wezel (1996), providing also positive results. GA other than ANN are also used with other models to predict financial failure: Back, Laitinen, \& Sere (1996), Back, Laitinen, Sere, \& van Wezel (1996) used genetic algorithms also compared to statistical measures in bankruptcy prediction, finding significant differences in failure prediction accuracy. An interesting literature review of methods that use fuzzy logic and genetic algorithms alone and in combination with other methods for bankruptcy prediction refers to Chou, Hsieh, \& Qiu (2017).

\subsection{The Approach Applied in This Study}

The literature showed that both genetic algorithms and fuzzy logic have been already used to predict bankruptcy, often in combination with other techniques, mostly with artificial neural networks. But cash flow ratios were rarely adopted alone as the input as they were often used in conjunction with other elements, like accruals, news, and other data. Also, in most of the experiments, the companies composing the sample, were mostly from the same industry, or size. And when that was not the case, they were from the same country, making comparisons with other countries studies difficult, due to the different country risk these companies were exposed to. An example of study that try to analyze the predictability of financial distress is the one carried out by Laitinen \& Suvas (2013) which showed adequate but significantly different AUC results across several European countries.

This study tries to demonstrate that using solely cash flow ratios and applying modern techniques such as genetic 
algorithms and fuzzy logic it is possible to assess the financial stability of a business, and eventually predict its bankruptcy. Artificial neural networks were not used because 1) they adopt a Boolean logic, where an element can be either 1 or 0 (it means either to be part of a set or not to be part of a set; and 2) the lack of clarity and transparency (it is not possible to not know with certainty what happens in each stage of the process). As said, it was preferred the fuzzy logic - a method that was concretely developed by Zadeh (1965) - that permits to obtain a "degree of membership" with a continuous number from 0 to 1 (not only black or white, but different levels of gray). This method is transparent: once set the "fuzzy rules", the rules on which the fuzzy logic behaves to assign the degrees of membership to a class, there are no black boxes during the process.

The hypothesis of this work is that cash flow ratios are so effective in assessing bankruptcy that using the modern techniques of fuzzy logic and genetic algorithms it will be possible to predict bankruptcy for all these companies considered.

\section{Method}

To test the goodness of the discriminatory power of ratios based only on cash with the use of genetic algorithms and fuzzy logic, financial data derived from Orbis database were used. Orbis is property of Bureau van Dijk (here after, BvD), a worldwide Data Provider belonging to Moody's Group. All data have been extracted from internal database of modefinance, a rating agency, ESMA certified, established in Trieste, Italy. The dataset used in this article includes companies based in Germany (DE), Spain (ES), France (FR), Great Britain (GB) and Italy (IT) and belonging to five Macro Sectors, clustered according to Nace Codes (4 digit) (Table 1).

Table 1. Macro Sector classification

\begin{tabular}{ll}
\hline Macro Sector & Nace Codes (4 digit) \\
\hline Agriculture & $0110: 0129 ; 0140: 0220: 0240: 0322 ; 8130$ \\
\hline Industry & $0130 ; 0230 ; 0500: 3320 ; 3831 ; 3832 ; 5800: 5819 ; 5920 ; 9512 ; 9524$ \\
\hline Services & $3700: 3830 ; 3900 ; 4110 ; 5200: 5320 ; 5820: 5914 ; 6000: 6399 ;$ \\
& $6800: 7000 ; 7020: 7331: 7733: 8129 ; 8200: 9511 ; 9600: 9900$ \\
\hline Construction & $4100 ; 4120: 4399 ; 7732$ \\
\hline Commerce and Food & $4500: 5122 ; 5500: 5630 ; 9520: 9523 ; 9525: 9529$ \\
\hline
\end{tabular}

The table reports the Macro Sectors and the corresponding Nace codes included in each of them.

To show a first evaluation of the creditworthiness for all companies in the data sample, the modefinance MORE model was employed. MORE (Multi Objective Rating Evaluation) is modefinance property algorithm for credit scoring, based on financial ratios calculated on the last available financial statement. The MORE scale includes ten classes, $\{\mathrm{D}, \mathrm{C}, \mathrm{CC}, \mathrm{CCC}, \mathrm{B}, \mathrm{BB}, \mathrm{BBB}, \mathrm{A}, \mathrm{AA}, \mathrm{AAA}\}$, where D represents the worst class and AAA the best. For sack of clarity, MORE scale was converted from letters to integers.

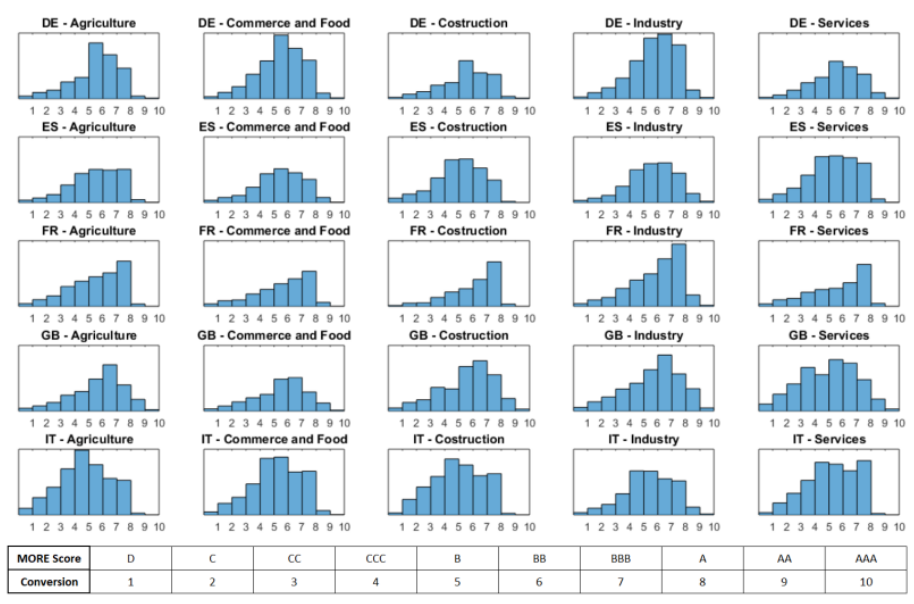

Figure 1. MORE Score distribution at Country-Sector level 
Looking at the MORE distribution for Country-Sectors pairs (Figure 1), it is possible to denote a strict difference on MORE scores between north countries, Germany, France and Great Britain, and south countries, Italy, and Spain. Most of north countries are characterized by median values around $7-8$ (that is, BBB - A) while medians of south countries range between 6 and 7 (BB-BBB). By focusing on sector comparison, industry sector turns out to be the best performer in terms of creditworthiness while agriculture presents a lower score than others. In general, France shows the best scores respect to other countries. In such regard, it is relevant to know that while companies based in Italy, Spain and France must publish both the balance sheet and the income statement, not all companies that are established in Germany and Great Britain are bind to publish the income statement. Afterward, it will be evident while observing the percentage of financial items present in the dataset for each couple Country-Sector.

Companies were selected and classified into two groups, active and defaulted, based on the information on the last legal event for the company (the legal events included in the default definition are reported in Table 2). When occurs, consolidated financial statement was preferred to the unconsolidated account. In the active group, financials data for the years from 2015 to 2017 were included.

For the defaulted group, the accepted time interval for the financial statement can range from 2015 to 2018. For each defaulted company only financial statements for the last and one to last year before default were considered. Approximately $47 \%$ of last available financials were dated 2017, the rest 53\% at 2018. For instance, if a company defaulted in 2018, cash flow figures from years 2016 to 2017 were employed to calculate the ratios referring to 2017, excluding the year in which default occurred. The time lag allows the model to predict default one year before it occurs.

Table 2. Orbis legal event definitions

\begin{tabular}{ll}
\hline Legal Event & Description \\
\hline Active (default of payment) & The term "default" should be distinguished from the terms "insolvency" \\
& and "bankruptcy". "Default" essentially means a debtor has not paid a \\
debt. "Insolvency" is a legal term meaning that a debtor is unable to pay \\
his debts. "Bankruptcy" is a legal finding that imposes court supervision \\
over the financial affairs of those who are insolvent of in default.
\end{tabular}

Active (insolvency proceedings) Here the company is declared insolvent. The company remains active, though is in administration or receivership or under a scheme of arrangement. During this period, the company is usually placed under the protection of a law and continues operating and repaying creditors and tries to reorganize and return to normal operating. At the end, the company will either return to normal operating (the default of payment was thus temporary); or will be recognized (parts of its activity can be restructured or sold); or will be liquidated.

\begin{tabular}{ll}
\hline Bankruptcy & $\begin{array}{l}\text { Bankruptcy is a legally declared inability of a company to pays its } \\
\text { creditors. The company is in the process of bankruptcy. The assets are } \\
\text { being sold in order to repay the creditors. At the end the company will be } \\
\text { dissolved and will no longer exist. }\end{array}$ \\
\hline Dissolved & $\begin{array}{l}\text { The company has been dissolved at the end of a bankruptcy process or } \\
\text { there was a bankruptcy declared into an insolvency or liquidation } \\
\text { proceeding. }\end{array}$ \\
\hline
\end{tabular}

Source: https://orbis.bvdinfo.com

The table reports the list of legal events included in the default definition along with the public description provided. In some countries, there is a lack of companies in 'Bankruptcy' (Table 3). A possible explanation is due to the different law system: Great Britain is the only country included in the analysis using the common law tradition. Moreover, it was found an extremely limited number of bankrupted companies in Germany, a country that adopt (like France, Italy, and Spain) the civil law system. 'Active' (insolvency proceedings) turns out to be the most frequent legal event among negative status and refers to companies which, after insolvency disclosure, are placed under law 
protection and arrangement. For such reason, the definition imposed to identify a company as defaulted plays a fundamental role in this work.

Table 3. Number of companies classified for legal events and country

\begin{tabular}{lllllll}
\hline & \multicolumn{2}{l}{ Legal Events per Country } & & & \\
\hline Legal Event & Germany & Spain & France & Great Britain & Italy & Total \\
\hline Active & 29178 & 60562 & 271789 & 41538 & 287916 & 690983 \\
\hline & $87.9 \%$ & $96.2 \%$ & $97.1 \%$ & $93.6 \%$ & $96.4 \%$ & \\
\hline Active (default of payment) & 2916 & 2 & 0 & 128 & 2521 & 5567 \\
\hline & $8.8 \%$ & $0.0 \%$ & $0.0 \%$ & $0.3 \%$ & $0.8 \%$ & \\
\hline Active (insolvency proceedings) & 1087 & 1659 & 5755 & 2720 & 220 & 11441 \\
\hline & $3.3 \%$ & $2.6 \%$ & $2.1 \%$ & $6.1 \%$ & $0.1 \%$ & \\
\hline Bankruptcy & 2 & 747 & 837 & 0 & 5613 & 7199 \\
\hline & $0.0 \%$ & $1.2 \%$ & $0.3 \%$ & $0.0 \%$ & $1.9 \%$ & \\
\hline Dissolved (bankruptcy) & 0 & 0 & 1497 & 1 & 2436 & 3934 \\
\hline & $0.0 \%$ & $0.0 \%$ & $0.5 \%$ & $0.0 \%$ & $0.8 \%$ & \\
\hline Total & 33183 & 62970 & 279878 & 44387 & 298706 & 719124 \\
\hline
\end{tabular}

The table reports the number of companies for each couple Legal Event - Country.

Table 4 provides the characteristics of the whole group of companies employed in this study (the total number is 719124), considering the legal status (active $-98.45 \%$ - or defaulted, $1.55 \%$ ), the Sectors and the Countries in which operate. In Germany the percentage of defaulted companies is higher than in the other countries considered in this analysis; this is true for all the sectors, even if for 'Industry' the German percentage of defaulted companies is closer to the data of the other countries. 'Construction' is the sector with the highest percentage of defaulted companies in all the countries, even if with different weights.

Table 4. Number of companies classified for legal status, country, and sector

\begin{tabular}{lllllll}
\hline Country & Sector & No. Companies & \multicolumn{2}{l}{ Active Companies } & \multicolumn{2}{l}{ Default Companies } \\
\hline Germany & Agriculture & 288 & 240 & $83.3 \%$ & 48 & $16.7 \%$ \\
& Commerce and food & 9201 & 7974 & $86.7 \%$ & 1227 & $13.3 \%$ \\
& Construction & 2034 & 1448 & $71.2 \%$ & 586 & $28.8 \%$ \\
& Industry & 10134 & 9525 & $94.0 \%$ & 609 & $6.0 \%$ \\
& Services & 11526 & 9991 & $86.7 \%$ & 1535 & $13.3 \%$ \\
\hline Spain & Agriculture & 2494 & 2447 & $98.1 \%$ & 47 & $1.9 \%$ \\
& Commerce and food & 22962 & 22166 & $96.5 \%$ & 796 & $3.5 \%$ \\
& Construction & 5888 & 5572 & $94.6 \%$ & 316 & $5.4 \%$ \\
& Industry & 13789 & 13303 & $96.5 \%$ & 486 & $3.5 \%$ \\
& Services & 17837 & 17074 & $95.7 \%$ & 763 & $4.3 \%$ \\
\hline France & Agriculture & 5353 & 5221 & $97.5 \%$ & 132 & $2.5 \%$ \\
& Commerce and food & 101638 & 98621 & $97.0 \%$ & 3017 & $3.0 \%$ \\
& Construction & 37231 & 35549 & $95.5 \%$ & 1682 & $4.5 \%$ \\
& Industry & 33064 & 31771 & $96.1 \%$ & 1293 & $3.9 \%$ \\
\hline
\end{tabular}




\begin{tabular}{lllllll}
\hline & Services & 102592 & 100627 & $98.1 \%$ & 1965 & $1.9 \%$ \\
\hline Great Britain & Agriculture & 516 & 493 & $95.5 \%$ & 23 & $4.5 \%$ \\
& Commerce and food & 10605 & 9947 & $93.8 \%$ & 658 & $6.2 \%$ \\
& Construction & 3263 & 2815 & $86.3 \%$ & 448 & $13.7 \%$ \\
& Industry & 9020 & 8580 & $95.1 \%$ & 440 & $4.9 \%$ \\
& Services & 20983 & 19730 & $93.9 \%$ & 1280 & $6.1 \%$ \\
\hline Italy & Agriculture & 8683 & 8589 & $98.9 \%$ & 94 & $1.1 \%$ \\
& Commerce and food & 81721 & 78534 & $96.1 \%$ & 3187 & $3.9 \%$ \\
& Construction & 41320 & 39258 & $95.0 \%$ & 2062 & $5.0 \%$ \\
& Industry & 62942 & 59922 & $95.2 \%$ & 3020 & $4.8 \%$ \\
& Services & 104040 & 101613 & $97.7 \%$ & 2427 & $2.3 \%$
\end{tabular}

The table reports the number of companies retrieved for Country, Sector, and status.

Due to methodological differences concerning the financial statements registered in each country, in this paper it was adopted the standard format for the financial statement proposed by BvD (Table 5). But the use of this compact representation requires detailing more some items; in particular:

- Cash \& cash equivalent has been considered as part of Other current assets along with other credits (such as tax credits, credits from subsidiaries etc.), and short term financial securities;

- Other shareholder funds include, among all, also Profit and loss for period, Retained profits/losses and Treasury shares;

- Provisions are already included in Other non-current liabilities;

- Long term debt and loans represent, respectively, long term financial debts and short term financial debts;

- Operating revenue is given by the sum of Sales and other revenues: the latter are not showed in the picture;

- Interest paid is already included in financial expenses.

Table 5. The Financial Statement format used in the analysis

\begin{tabular}{lll}
\hline Balance Sheet & & Income Statement \\
\hline Fixed Assets & Shareholder funds & Operating revenue \\
\hline Intangible fixed assets & Capital & Sales \\
\hline Tangible fixed assets & Other shareholder funds & Total costs \\
\hline Other fixed assets & Treasury Shares & Material costs \\
\hline Current assets & Non current liabilities & Service costs \\
\hline Stocks & Long term debt & Cost of employees \\
\hline Debtors & Other non current liabilities & Ebitda \\
\hline Other current assents & Provisions & Depreciation \\
\hline \multicolumn{1}{c}{ Cash \& cash equivalent } & Current liabilities & Ebit \\
\hline Total Assets & Loans & Financial revenues \\
\hline & Creditors & Financial expenses \\
\hline & Other current liabilities & Interest paid \\
\hline & Total shareholder funds and liabilities & Financial profit \& loss \\
\hline & & Profit and loss before tax \\
\hline & & Taxation \\
\hline & & Profit and loss for period \\
\hline
\end{tabular}


The table reports the financial statement format proposed by BvD. All items in grey identify sums of other figures.

The rules related to the publication of financial statements tend to differ country by country. Table 6 reports the results of the analysis of missing relevant variables regarding either the balance sheet or the income statement, starting from the financial statement of all companies included in the sample. The results are represented as a percentage of companies, for each couple Country-Sector. It is immediately evident that, while financial items of balance sheet have a low rate of missing values, variables related to income statement (e.g. Sales, P/L for period, Interest paid and Ebitda) are characterized by remarkably high percentage of absent values. Being Sales truly relevant for this work, it was used a technic, explained later, to replace the relevant missing values for companies operating in Great Britain and Germany. The percentage of missing values in the other countries under examination is extremely low, allowing using the base information directly.

Table 6. The percentage of missing variables at country and sector level

\begin{tabular}{|c|c|c|c|c|c|c|c|c|c|}
\hline Country & Sector & Creditors & Debtors & $\begin{array}{l}\text { Long } \\
\text { term debt }\end{array}$ & Loans & Sales & $\begin{array}{l}\mathrm{P} / \mathrm{L} \text { for } \\
\text { period }\end{array}$ & $\begin{array}{l}\text { Interest } \\
\text { paid }\end{array}$ & Ebitda \\
\hline \multirow[t]{5}{*}{ Germany } & Agriculture & $14.41 \%$ & $1.56 \%$ & $0.52 \%$ & $12.85 \%$ & $65.28 \%$ & $21.18 \%$ & $16.67 \%$ & $16.32 \%$ \\
\hline & Commerce and food & $13.49 \%$ & $1.42 \%$ & $0.42 \%$ & $11.15 \%$ & $54.15 \%$ & $20.31 \%$ & $12.60 \%$ & $12.61 \%$ \\
\hline & Construction & $21.14 \%$ & $3.52 \%$ & $0.79 \%$ & $19.35 \%$ & $66.76 \%$ & $32.52 \%$ & $27.48 \%$ & $27.70 \%$ \\
\hline & Industry & $9.86 \%$ & $0.37 \%$ & $0.09 \%$ & $7.75 \%$ & $51.33 \%$ & $16.05 \%$ & $5.21 \%$ & $5.30 \%$ \\
\hline & Services & $13.40 \%$ & $2.00 \%$ & $0.73 \%$ & $12.04 \%$ & $35.84 \%$ & $21.69 \%$ & $12.90 \%$ & $12.60 \%$ \\
\hline \multirow[t]{5}{*}{ Spain } & Agriculture & $2.61 \%$ & $0.04 \%$ & $19.87 \%$ & $0.72 \%$ & $3.37 \%$ & $0.02 \%$ & $1.08 \%$ & $0.00 \%$ \\
\hline & Commerce and food & $1.56 \%$ & $0.03 \%$ & $21.96 \%$ & $0.56 \%$ & $2.54 \%$ & $0.03 \%$ & $1.70 \%$ & $0.03 \%$ \\
\hline & Construction & $1.18 \%$ & $0.04 \%$ & $23.06 \%$ & $0.70 \%$ & $6.45 \%$ & $0.12 \%$ & $1.59 \%$ & $0.10 \%$ \\
\hline & Industry & $0.63 \%$ & $0.01 \%$ & $17.58 \%$ & $0.38 \%$ & $1.61 \%$ & $0.01 \%$ & $1.45 \%$ & $0.01 \%$ \\
\hline & Services & $5.77 \%$ & $0.06 \%$ & $17.92 \%$ & $1.04 \%$ & $17.75 \%$ & $0.09 \%$ & $2.64 \%$ & $0.08 \%$ \\
\hline \multirow[t]{5}{*}{ France } & Agriculture & $0.00 \%$ & $0.00 \%$ & $0.00 \%$ & $0.00 \%$ & $0.07 \%$ & $0.07 \%$ & $38.98 \%$ & $0.07 \%$ \\
\hline & Commerce and food & $0.00 \%$ & $0.00 \%$ & $0.00 \%$ & $0.00 \%$ & $0.16 \%$ & $0.16 \%$ & $34.89 \%$ & $0.16 \%$ \\
\hline & Construction & $0.00 \%$ & $0.00 \%$ & $0.00 \%$ & $0.00 \%$ & $0.27 \%$ & $0.26 \%$ & $40.67 \%$ & $0.26 \%$ \\
\hline & Industry & $0.02 \%$ & $0.00 \%$ & $0.02 \%$ & $0.02 \%$ & $0.27 \%$ & $0.26 \%$ & $26.05 \%$ & $0.31 \%$ \\
\hline & Services & $0.00 \%$ & $0.00 \%$ & $0.01 \%$ & $0.00 \%$ & $0.08 \%$ & $0.07 \%$ & $46.09 \%$ & $0.08 \%$ \\
\hline \multirow{5}{*}{$\begin{array}{l}\text { Great } \\
\text { Britain }\end{array}$} & Agriculture & $0.39 \%$ & $0.39 \%$ & $12.31 \%$ & $0.39 \%$ & $97.87 \%$ & $4.17 \%$ & $4.46 \%$ & $8.04 \%$ \\
\hline & Commerce and food & $0.42 \%$ & $0.22 \%$ & $18.43 \%$ & $0.33 \%$ & $98.54 \%$ & $5.01 \%$ & 5.48 & $10.48 \%$ \\
\hline & Construction & $0.21 \%$ & $0.20 \%$ & $20.26 \%$ & $0.21 \%$ & $99.23 \%$ & $11.20 \%$ & $11.78 \%$ & $22.36 \%$ \\
\hline & Industry & $0.58 \%$ & $0.14 \%$ & $14.04 \%$ & $0.47 \%$ & $94.66 \%$ & $3.60 \%$ & $4.54 \%$ & $8.59 \%$ \\
\hline & Services & $0.77 \%$ & $0.61 \%$ & $27.17 \%$ & $0.64 \%$ & $97.68 \%$ & $5.19 \%$ & $5.83 \%$ & $30.22 \%$ \\
\hline \multirow[t]{5}{*}{ Italy } & Agriculture & $0.00 \%$ & $0.00 \%$ & $0.00 \%$ & $0.00 \%$ & $0.00 \%$ & $0.00 \%$ & $15.55 \%$ & $15.81 \%$ \\
\hline & Commerce and food & $0.00 \%$ & $0.00 \%$ & $0.00 \%$ & $0.00 \%$ & $0.00 \%$ & $0.00 \%$ & $8.56 \%$ & $7.95 \%$ \\
\hline & Construction & $0.00 \%$ & $0.00 \%$ & $0.00 \%$ & $0.00 \%$ & $0.00 \%$ & $0.00 \%$ & $11.47 \%$ & $20.93 \%$ \\
\hline & Industry & $0.00 \%$ & $0.00 \%$ & $0.00 \%$ & $0.00 \%$ & $0.00 \%$ & $0.00 \%$ & $6.41 \%$ & $5.86 \%$ \\
\hline & Services & $0.00 \%$ & $0.00 \%$ & $0.00 \%$ & $0.00 \%$ & $0.00 \%$ & $0.00 \%$ & $12.78 \%$ & $15.03 \%$ \\
\hline
\end{tabular}

The table reports the high percentage of companies based in Germany and Great Britain without information on Sales and on Ebitda. For Ebitda the percentage is less relevant, but it is comparable to Italy.

To converge towards a credit scoring model, cash flow ratios were selected, with a double goal:

- Covering more and different valuation areas of business performance, going from purely balance sheet and 
income statement components to financial one;

- Avoiding multicollinearity issues.

While first goal has been headed a priori, the second has been pursued through Pearson correlation coefficient. After computing the Pearson coefficient for all eleven ratios, we have ruled out those showing a correlation coefficient greater than $60 \%$ (this threshold is adopted by modefinance in developing credit scoring models), in absolute terms.

Table 7. Correlation matrix

\begin{tabular}{|c|c|c|c|c|c|c|c|c|c|c|c|}
\hline & Free & Operating & Operating & Self & Operating & Operating & Self & Debt & Operating & (Ebitda-NFP) & \multirow{2}{*}{$\begin{array}{l}\text { Self } \\
\text { Financing }\end{array}$} \\
\hline & Cashflow & Cashflow & Cashflow & Financing & Cashflow & Working & Financing & Service & Cashflow & Total & \\
\hline & to Total & to Current & to Total & to Interest & to Interest & Capital on & to Total & Coverage & to Sale's & \multirow[t]{3}{*}{ Asset } & to Current \\
\hline & Asset & Liabilities & Liabilities & Paid & Paid & Total & Asset & Ratio & & & Liabilities \\
\hline & & & & & & Asset & & & & & \\
\hline Free & $100.0 \%$ & $0.6 \%$ & $7.4 \%$ & $1.2 \%$ & $0.8 \%$ & $-92.4 \%$ & $-85.6 \%$ & $0.3 \%$ & $2.8 \%$ & \multirow[t]{3}{*}{$0.3 \%$} & $0.6 \%$ \\
\hline Cashflow to & & & & & & & & & & & \\
\hline Total Asset & & & & & & & & & & & \\
\hline Operating & $0.6 \%$ & $100.0 \%$ & $5.4 \%$ & $0.1 \%$ & $0.5 \%$ & $0.0 \%$ & $0.7 \%$ & $0.2 \%$ & $0.3 \%$ & \multirow[t]{4}{*}{$0.0 \%$} & $3.5 \%$ \\
\hline Cashflow to & & & & & & & & & & & \\
\hline Current & & & & & & & & & & & \\
\hline Liabilities & & & & & & & & & & & \\
\hline Operating & $7.4 \%$ & $5.4 \%$ & $100.0 \%$ & $4.4 \%$ & $13.9 \%$ & $-1.4 \%$ & $11.4 \%$ & $7.0 \%$ & $3.7 \%$ & \multirow[t]{4}{*}{$3.4 \%$} & $58.2 \%$ \\
\hline Cashflow to & & & & & & & & & & & \\
\hline Total & & & & & & & & & & & \\
\hline Liabilities & & & & & & & & & & & \\
\hline Self & $1.2 \%$ & $0.1 \%$ & $4.4 \%$ & $100.0 \%$ & $58.3 \%$ & $0.7 \%$ & $1.1 \%$ & $9.9 \%$ & $0.0 \%$ & \multirow[t]{3}{*}{$7.0 \%$} & $6.7 \%$ \\
\hline Financing to & & & & & & & & & & & \\
\hline Interest Paid & & & & & & & & & & & \\
\hline Operating & $0.8 \%$ & $0.5 \%$ & $13.9 \%$ & $58.3 \%$ & $100.0 \%$ & $0.3 \%$ & $2.0 \%$ & $18.5 \%$ & $0.4 \%$ & \multirow[t]{3}{*}{$9.5 \%$} & $11.3 \%$ \\
\hline Cashflow to & & & & & & & & & & & \\
\hline Interest Paid & & & & & & & & & & & \\
\hline Operating & $-92.4 \%$ & $0.0 \%$ & $-1.4 \%$ & $0.7 \%$ & $0.3 \%$ & $100.0 \%$ & $92.2 \%$ & $0.3 \%$ & $-3.5 \%$ & \multirow[t]{4}{*}{$0.5 \%$} & $13.2 \%$ \\
\hline Working & & & & & & & & & & & \\
\hline Capital on & & & & & & & & & & & \\
\hline Total Asset & & & & & & & & & & & \\
\hline Self & $-85.6 \%$ & $0.7 \%$ & $11.4 \%$ & $1.1 \%$ & $2.0 \%$ & $92.2 \%$ & $100.0 \%$ & $1.1 \%$ & $-0.4 \%$ & \multirow[t]{3}{*}{$1.0 \%$} & $21.4 \%$ \\
\hline Financing to & & & & & & & & & & & \\
\hline Total Asset & & & & & & & & & & & \\
\hline Debt Service & $0.3 \%$ & $0.2 \%$ & $7.0 \%$ & $9.9 \%$ & $18.5 \%$ & $0.3 \%$ & $1.1 \%$ & $100.0 \%$ & $0.1 \%$ & \multirow[t]{3}{*}{$48.7 \%$} & $5.1 \%$ \\
\hline Coverage & & & & & & & & & & & \\
\hline Ratio & & & & & & & & & & & \\
\hline Operating & $2.8 \%$ & $0.3 \%$ & $3.7 \%$ & $0.0 \%$ & $0.4 \%$ & $-3.5 \%$ & $-0.4 \%$ & $0.1 \%$ & $100.0 \%$ & \multirow[t]{3}{*}{$0.0 \%$} & $0.6 \%$ \\
\hline Cashflow to & & & & & & & & & & & \\
\hline Sales & & & & & & & & & & & \\
\hline (Ebitda-NFP) & $0.3 \%$ & $0.0 \%$ & $3.4 \%$ & $7.0 \%$ & $9.5 \%$ & $0.5 \%$ & $1.0 \%$ & $48.7 \%$ & $0.0 \%$ & \multirow[t]{3}{*}{$100.0 \%$} & $5.0 \%$ \\
\hline to Total & & & & & & & & & & & \\
\hline Asset & & & & & & & & & & & \\
\hline Self & $0.6 \%$ & $3.5 \%$ & $57.2 \%$ & $6.7 \%$ & $11.3 \%$ & $13.2 \%$ & $21.4 \%$ & $5.1 \%$ & $0.6 \%$ & \multirow[t]{4}{*}{$5.0 \%$} & $100.0 \%$ \\
\hline Financing to & & & & & & & & & & & \\
\hline Current & & & & & & & & & & & \\
\hline Liabilities & & & & & & & & & & & \\
\hline
\end{tabular}


The table reports correlation coefficient among the ratios selected in the first step. The cells in gray show a high correlation that suggests excluding these ratios.

After removing Operating Working Capital to Total Asset and Self Financing to Total Asset from the set of ratios to use in the model, because of their correlation coefficient ranging between $86 \%$ and $92 \%$, it was possible to derive nine essential ratios capable of supplying a global overview of the company from a creditworthiness point of view.

In Table 8 the list of cash flow ratios used in the study is reported, with the relative legend of the underlying formulas. As already underlined, all variables have been derived from the Standard Financial Statement proposed by BvD.

Table 8. Selected cash flow ratios

\begin{tabular}{lll}
\hline Cash Flow Ratios & Formula \\
\hline Free Cash Flow to Total Asset & $\begin{array}{l}\text { (T0.Ebit*(1-tax_rate)+T0.Depreciation-Capex+Globle } \\
\text { Capital)/T0.Total_Asset }\end{array}$ \\
\hline Operating Cash Flow to Current Liabilities & (Self Financing+Core Working Capital)/T0.Current_Liabilities \\
\hline Operating Cash Flow to Total Liabilities & (Self Financing+Core working Capital)/T0.Total_Liabilities \\
\hline Self Financing to Interest Paid & Self Financing/T0.Interest_Paid \\
\hline Operating Cash Flow to Interest Paid & (Self Financing+Core Working Capital)/T0.Interest_Paid \\
\hline Operating Cash Flow to Sales & (Self Financing+Core Working Capital)/T0.Sales \\
\hline Ebitda to NFP & (T0.Ebitda-NFP)/T0.Total_Asset \\
\hline Debt Service Coverage Ratio & (T1.Cash\&CashEquivalent+Self Financing+Core & Working \\
\hline Self Financing to Current Liabilities & Capital)/(Total_Financial_Debts+T0.Interest_Paid) \\
\hline
\end{tabular}

The table reports the cash flow ratios employed in the model and the formula used to calculate them.

It was considered appropriate to include in the set of ratios one indicator based exclusively on the last available year, which is "(Ebitda - Net Financial Position) to Total Asset". Nowadays, this variable covers an important role, in particular in banking environment, in defining the maximum amount of borrowing to a company.

The roots $\mathrm{T} 0$ and $\mathrm{T} 1$ at the beginning of some figures indicate, respectively, the last and the second to last available year of the financial statement. In case of defaulted companies, T0 refers to the last year before the event of default while $\mathrm{T} 1$ refers to the previous one, which is the year before $\mathrm{T} 0$.

Table 8 shows the macro-formulas with only a few details relating to the balance sheet items used. The complete formulation adopted can be seen in Table 9.

Table 9. The Balance Sheet items e the underlined formulas

\begin{tabular}{ll}
\hline Legend & Formula \\
\hline Global Working Capital & $\begin{array}{l}\text { T0.Creditors-T1.Creditors+T1.Debtors-T0.Debtors+T1.Stocks-T0.Stocks+T1.Other_ } \\
\text { Current_Asset-T0.Other_Current_Asset-T1.Cash\&CashEquivalent+T0.Cash\&CashE } \\
\text { quivalent+T0.Other_Current_Liabilities-T1.Other_Current_Liabilities }\end{array}$ \\
\hline Core Working Capital & T0.Creditors-T1.Creditors+T1.Debtors-T0.Debtors+T1.Stocks-T0.Stocks \\
\hline Capex & $\begin{array}{l}\text { T0.Depreciation+T0.Tangible/Intangible_Fixed_Assets-T1.Tangible/Intangible_Fixe } \\
\text { d_Assets }\end{array}$ \\
\hline Self Financing & T0.PL_for_Period+T0.Depreciation+T0.Provisions-T1.Provisions \\
\hline NFP & T0.Loans+T0.Long_Term_Debt-T0.Cash\&CashEquivalent \\
\hline Total Financial Debts & T0.Loans+T0.Long_Term_Debt \\
\hline
\end{tabular}


The table reports the formulas employed to calculate the Balance Sheet items used in the cash flow ratios.

Previously, it was noted how certain financial variables tend not to be present in the financial statements published by companies. The figure of the financial statement with the highest percentage of missing values, regarding Germany and Great Britain, is Sales. Being this variable rather important for the computation of the Operating Cash Flow to Sales ratio, it was decided to build alongside the Operating Cash Flow to Total Asset ratio, not present in the table above, which is used to replace the ratio with Sales in case of missing value.

From a technical point of view, this deviation requires adopting normalization techniques capable of allowing a consistent and standardized comparison between different ratios, especially when analyzing companies that have several missing variables in their financial statements. The normalization implicitly assigns a score to each ratio used based on the goodness, in terms of creditworthiness, of its initial value. A way to run this procedure is through the fuzzy logic and it is quite common for most of the credit scoring models. Note 1 explains as it works in ratio calculation to convert the original performance of the various ratios into a homogeneous evaluation scale.

The process that permits to transform the original values in a set of homogeneous values is called normalization: it consists in converting the values of the ratios from an interval [- Inf, + Inf] to [0, 1], where 0 represents the worst score and 1 the best. The new values assigned to the indicators would thus be immediately comparable and, consequently, analyzable to assess the creditworthiness of a company. To build a credit scoring algorithm, it is necessary to automate the normalization approach for all ratios to be used in the assessment: the fuzzy logic meets both needs of normalizing cash flow ratios while assigning a numerical score and automating the whole mechanism.

The conversion from $[-\operatorname{Inf},+\operatorname{Inf}]$ and $[0,1]$ requires the search of critical points, called nodes, for both the original values and scores of the ratios. Once nodes are set, all companies ratios can be automatically translated in new scores through a linear interpolation computation. Here below it is reported the formula of the linear interpolation used:

$$
\text { Score }_{\text {new }}=\frac{\left(\text { Ratio }_{\text {rawdata }}-\text { Ratio }_{\text {node }(b)}\right) * \operatorname{Score}_{\text {node }(a)}}{\left(\text { Ratio }_{\text {node }(a)}-\operatorname{Ratio}_{\text {node }(b)}\right)}-\frac{\left(\text { Ratio }_{\text {rawdata }}-\text { Ratio }_{\text {node }(a)}\right) * \operatorname{Score}_{\text {node }(b)}}{\left(\text { Ratio }_{\text {node }(a)}-\operatorname{Ratio}_{\text {node }(b)}\right)}
$$

Where:

Ratio $_{\text {rawdata }}=$ Original value of the ratio

Ratio $_{\text {node }(b)}=$ Previous node of the ratio

Ratio $_{\text {node( }(a)}=$ Current node of the ratio

Score $_{\text {node }(b)}=$ Previous node of the score

Score $_{\text {node }(a)}=$ Current node of the score

And:

Ratio $_{\text {node }(b)}<$ Ratio $_{\text {node }(a)}$

Once the respective values of each ratio converted to scale $[0,1]$ have been found, it is possible to proceed with the construction of a weighted cash flow scoring model in the following form:

$$
\text { Cashflow Score }=\sum_{j} w_{j} * R_{j}
$$

Where:

$w_{j}=j$-th weight

$R_{j}=j$-th ratio

$\sum_{j} w_{j}=1$

The weights, the ratios nodes, and the score nodes have been chosen with the aim of maximizing the discriminating power of the score between defaulted and active companies. The variables have been chosen to optimize the Area Under Curve (AUC).

The AUC is the area under the Cumulative Accuracy Profile curve (CAP), a measure of the model discriminating capacity. CAP (Satchell \& Xia, 2006) curves are constructed by sorting all (credit) scores from the worst to the best on the $x$ axis and then, for each $x$ (score) values, plotting on the $y$ axis the percentage $\mathrm{d}(x)$ of defaulters included within that credit score. It is natural to understand that a "perfect" scoring model will assign the lowest scores to the defaulters. Such model is described in the Figure 2, by the curve which is increasing linearly and then staying at one. 


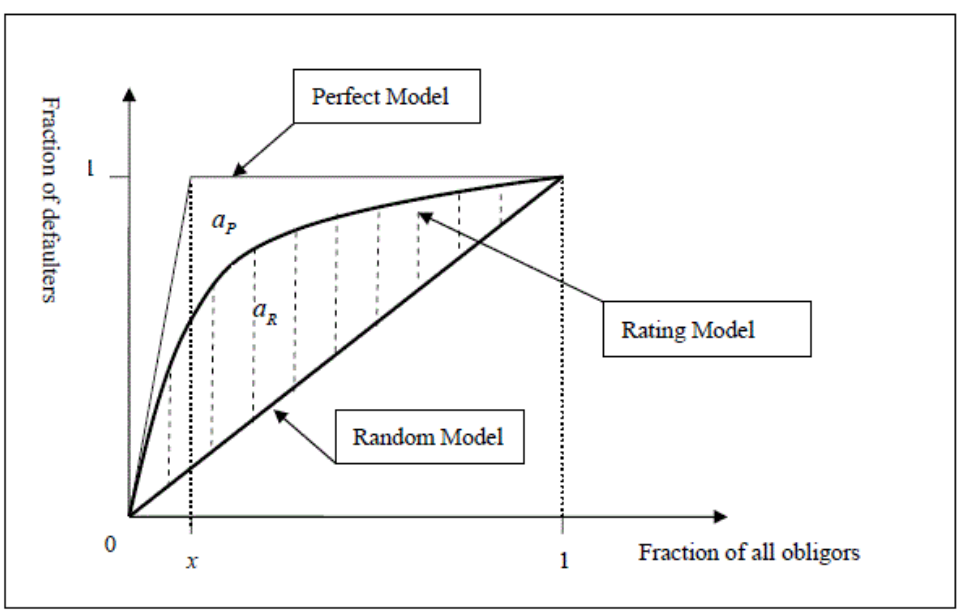

Figure 2. CAP representation (Baixauli \& Módica-Milo, 2010)

For a random model (with no discriminative power), a given fraction $x$ of debtors with the lowest rating scores will contain the same amount ( $x$ percent) of all defaulters. A real rating system will fit between these two extreme models. The AUC is a convenient measure for summarizing the performance of the graph of the CAP and calculated as the proportion of the area below the CAP relative to the total area below the "perfect model". A value of 0.5 indicates the random model, and a value of 1.0 indicates a perfect model.

The search of the optimal weights, ratios nodes and score nodes is therefore outlined as a constrained non-linear optimal problem where the variables mentioned represent the free parameters, while the variable to be maximized is represented by the AUC as an indicator of power discriminating between active and defaulted companies of the model.

From an academic point of view, AUC values can be assessed in the following way:

Table 10. Accuracy level of AUC

\begin{tabular}{llllll}
\hline AUC & {$[100 ; 90]$} & {$[90 ; 80]$} & {$[80 ; 70]$} & {$[70 ; 60]$} & {$[60 ; 50]$} \\
\hline Accuracy & Excellent & Good & Adequate & Poor & Fail \\
\hline
\end{tabular}

The non-linear problem described above was addressed using a Genetic Algorithm (GA) provided by MATLAB Optimization toolbox. Genetic algorithms are computational models based on theoretical concepts relating to Darwinian natural evolution, as described in the1. Introduction, in the creditworthiness valuation, in particular, genetic algorithms have been used by several authors, e.g. Huang, Zhan, Chen, \& Lü (2003) Abdou (2009), Fogarty (2012), with the aim, among others, of generating the linear functions coefficients underlying the regression models.

The operations performed by the genetic algorithms can be summarized in the following steps (D'Annunzio \& Falavigna, 2004):

- Random generation of a population of observation (in this article nodes and weights);

- For each observation, a fitness function is calculated based on the target variable to be optimized (in this work AUC);

- The algorithm identifies the random observations (parents) for which the fitness function provides the best performance;

- The best observations (parents) are recombined by the algorithm to generate new optimal observations (children);

- The observations (children) constitute a new population to which the above procedure is repeated starting from the second step;

- The algorithm stops when it is no longer possible to find better solutions. 
The results obtained through the GA in terms of AUC at Country-Sector level and the cash flow ratios that have shown the greatest discriminating power are presented in the next section.

\section{Results}

The model developed has been validated out of sample at Country and Sector level by maximizing the AUC measure, as key parameter to estimate the accuracy of the scoring model. Table 11 shows the AUC results for the twenty-five individual models, one for each Country and Sector pair, along with the optimal weights wj combined to the ratios.

Table 11. Model results at country and sector level

\begin{tabular}{|c|c|c|c|c|c|c|c|c|c|c|c|c|}
\hline Country & Sector & $\begin{array}{l}\text { AUC In } \\
\text { Sample }\end{array}$ & $\begin{array}{l}\text { AUC Out } \\
\text { of Sample }\end{array}$ & w1 & w2 & w3 & w4 & w5 & w6 & w7 & w8 & w9 \\
\hline \multirow[t]{5}{*}{ Germany } & Agriculture & 75.86 & 78.20 & 0.014 & 0.026 & 0.047 & 0.258 & 0.079 & 0.063 & 0.241 & 0.079 & 0.192 \\
\hline & Commerce and food & 84.33 & 92.57 & 0.096 & 0.039 & 0.065 & 0.256 & 0.054 & 0.111 & 0.165 & 0.108 & 0.106 \\
\hline & Construction & 75.84 & 83.69 & 0.027 & 0.034 & 0.021 & 0.445 & 0.022 & 0.036 & 0.042 & 0.158 & 0.217 \\
\hline & Industry & 78.12 & 85.15 & 0.016 & 0.085 & 0.016 & 0.307 & 0.012 & 0.016 & 0.092 & 0.205 & 0.251 \\
\hline & Services & 71.45 & 83.97 & 0.015 & 0.127 & 0.128 & 0.333 & 0.026 & 0.012 & 0.027 & 0.193 & 0.139 \\
\hline \multirow[t]{5}{*}{ Spain } & Agriculture & 81.33 & 82.57 & 0.151 & 0.072 & 0.012 & 0.484 & 0.014 & 0.017 & 0.178 & 0.034 & 0.036 \\
\hline & Commerce and food & 81.42 & 85.43 & 0.041 & 0.065 & 0.061 & 0.467 & 0.020 & 0.010 & 0.290 & 0.022 & 0.023 \\
\hline & Construction & 79.17 & 80.72 & 0.012 & 0.065 & 0.011 & 0.347 & 0.029 & 0.014 & 0.144 & 0.183 & 0.195 \\
\hline & Industry & 85.54 & 86.59 & 0.121 & 0.012 & 0.025 & 0.369 & 0.073 & 0.023 & 0.230 & 0.065 & 0.083 \\
\hline & Services & 79.42 & 83.67 & 0.075 & 0.024 & 0.033 & 0.445 & 0.062 & 0.030 & 0.033 & 0.100 & 0.197 \\
\hline \multirow[t]{5}{*}{ France } & Agriculture & 70.89 & 71.52 & 0.024 & 0.065 & 0.063 & 0.288 & 0.034 & 0.022 & 0.132 & 0.125 & 0.248 \\
\hline & Commerce and food & 71.70 & 73.36 & 0.012 & 0.017 & 0.026 & 0.242 & 0.036 & 0.023 & 0.309 & 0.116 & 0.217 \\
\hline & Construction & 74.89 & 76.18 & 0.044 & 0.013 & 0.012 & 0.284 & 0.022 & 0.040 & 0.286 & 0.024 & 0.275 \\
\hline & Industry & 73.25 & 74.29 & 0.014 & 0.016 & 0.036 & 0.476 & 0.029 & 0.016 & 0.025 & 0.034 & 0.355 \\
\hline & Services & 70.83 & 72.57 & 0.047 & 0.014 & 0.025 & 0.363 & 0.027 & 0.158 & 0.087 & 0.040 & 0.239 \\
\hline \multirow{5}{*}{$\begin{array}{l}\text { Great } \\
\text { Britain }\end{array}$} & Agriculture & 69.14 & 74.85 & 0.167 & 0.046 & 0.014 & 0.129 & 0.033 & 0.020 & 0.227 & 0.031 & 0.335 \\
\hline & Commerce and food & 67.51 & 68.80 & 0.317 & 0.013 & 0.078 & 0.311 & 0.051 & 0.012 & 0.085 & 0.104 & 0.030 \\
\hline & Construction & 72.63 & 79.01 & 0.056 & 0.107 & 0.027 & 0.068 & 0.017 & 0.054 & 0.148 & 0.169 & 0.355 \\
\hline & Industry & 65.00 & 72.86 & 0.130 & 0.101 & 0.111 & 0.108 & 0.109 & 0.107 & 0.117 & 0.102 & 0.116 \\
\hline & Services & 80.38 & 84.51 & 0.196 & 0.012 & 0.025 & 0.126 & 0.021 & 0.049 & 0.211 & 0.112 & 0.249 \\
\hline \multirow[t]{5}{*}{ Italy } & Agriculture & 79.01 & 79.58 & 0.042 & 0.018 & 0.059 & 0.094 & 0.014 & 0.024 & 0.230 & 0.020 & 0.500 \\
\hline & Commerce and food & 75.38 & 76.90 & 0.030 & 0.016 & 0.038 & 0.146 & 0.061 & 0.094 & 0.168 & 0.071 & 0.376 \\
\hline & Construction & 77.72 & 78.47 & 0.032 & 0.011 & 0.027 & 0.130 & 0.017 & 0.024 & 0.181 & 0.075 & 0.503 \\
\hline & Industry & 83.44 & 83.76 & 0.015 & 0.047 & 0.022 & 0.203 & 0.010 & 0.083 & 0.032 & 0.178 & 0.410 \\
\hline & Services & 79.49 & 80.50 & 0.024 & 0.016 & 0.037 & 0.021 & 0.021 & 0.011 & 0.327 & 0.018 & 0.524 \\
\hline
\end{tabular}

The table reports the AUC in sample and out of the sample of the model developed along with the weights of the ratios. The weights have been optimized by the algorithm to reach the highest AUC in sample for each pair Country-Sector. As all weights range between 0 and 1, it can be inferred that the greater the weight, the highest is the discriminatory power of the corresponding ratio in predicting the riskiness of the companies.

The algorithm provided one scoring model for each Country-Sector pair in the following form:

$$
L=w_{1} X_{1}+w_{2} X_{2}+w_{3} X_{3}+w_{4} X_{4}+w_{5} X_{5}+w_{6} X_{6}+w_{7} X_{7}+w_{8} X_{8}+w_{9} X_{9}
$$

Where: 
$X_{I}=$ Free Cash Flow to Total Asset

$X_{2}=$ Operating Cash Flow to Current Liabilities

$X_{3}=$ Operating Cash Flow to Total Liabilities

$X_{4}=$ Self Financing to Interest Paid

$X_{5}=$ Operating Cash Flow to Interest paid

$X_{6}=$ Operating Cash Flow to Sales

$X_{7}=($ Ebitda - NFP $)$ to Total Asset

$X_{8}=$ Debt Service Coverage Ratio

$X_{9}=$ Self Financing to Current Liabilities

For all models developed, AUC out of sample reached highest values than AUC in sample. The AUC values in sample proved to be adequate for most of the models. It can be seen how the best results have been achieved mostly in Spain, where three out of five sectors, Construction and Services excluded, obtained good values of AUC. Also, Germany, Great Britain and Italy reached good results in one sector for each, respectively, Commerce and Food, Services, and Industry. Worst AUC in sample results have been obtained in Great Britain in three out of five sectors, Agriculture, Commerce and Food, and Industry, with values below the adequate threshold of 70 (see Table 10).

It can be observed a proper stability of the algorithm between in sample and out of sample measures for Spain, France, and Italy. AUC values, indeed, turn out to be remarkably similar in the two samples. On the contrary, all models for Germany and Great Britain, except for, respectively, Agriculture and Commerce and Food, provided more sharp differences between the two samples.

Overall, following the accuracy thresholds for AUC values, reliable results were obtained, both in sample and out of sample. By focusing on out of sample results, all models, except for GB - Commerce and Food, provided either adequate or good results or one excellent result. Figure 3 shows the particularly good performance of the algorithm for all sectors in Spain, with AUC values ranging from 80 to 87.

In Germany, apart from Agriculture sector where accuracy was just adequate, AUC range from 82 to, almost, 93: the sector Commerce and Food obtained, in particular, the best result overall with an AUC value over 90. On the other side, about all models for France, Great Britain and Italy sectors reached an adequate accuracy level. For GB Services, Italy - Industry and Italy - Services the algorithm was particularly efficient in predicting defaulted companies, in all other Country-Sector pairs the algorithm provided an average discriminatory power. The only negative result is represented by the model running on GB - Commerce and Food, where AUC accuracy is just 68.80, showing to be the worst result overall.

Figure 3 gives the graphic representation at Country and Sector level of the AUC accuracy reached by the algorithm out of sample, throughout CAP curves. Red and magenta lines represent, respectively, the random and perfect models while blue lines indicate the accuracy obtained by the algorithm. For few Country-Sector pairs, Great Britain especially, the model is characterized by stepped blue lines, due to the lack of a proper number of defaulted companies.
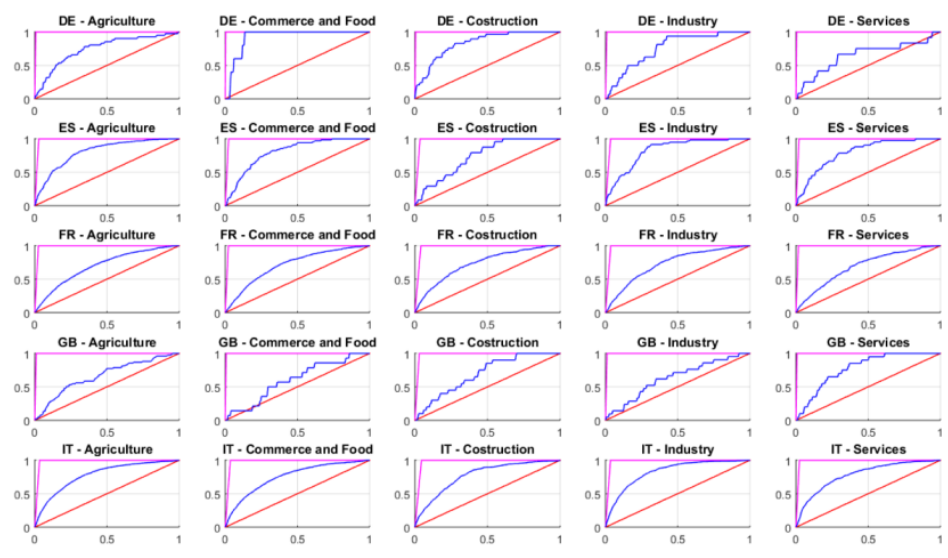

Figure 3. CAP representation at Country and Sector level 
Since all ratios have been previously normalized, the optimized weights can be considered as a measure of importance of the corresponding ratios in discriminating between good and bad companies. Overall, "Self-Financing to Current Liabilities" turns out to have highest weight value. Other ratios well discriminating are "Self-Financing to Interest Paid" and "Ebitda to NFP": the only exceptions to these two ratios occur for, respectively, Great Britain and Germany, where "Free Cash Flow to Total Asset" and "Debt Service Coverage Ratio", still respectively, are preferred. On the other side, all ratios using Operating Cash Flow at the numerator have a lower impact on the capability of the model to predict defaulted companies.

Figure 4 shows the cash flow scores obtained at Country and Sector level for defaulted and not defaulted companies.

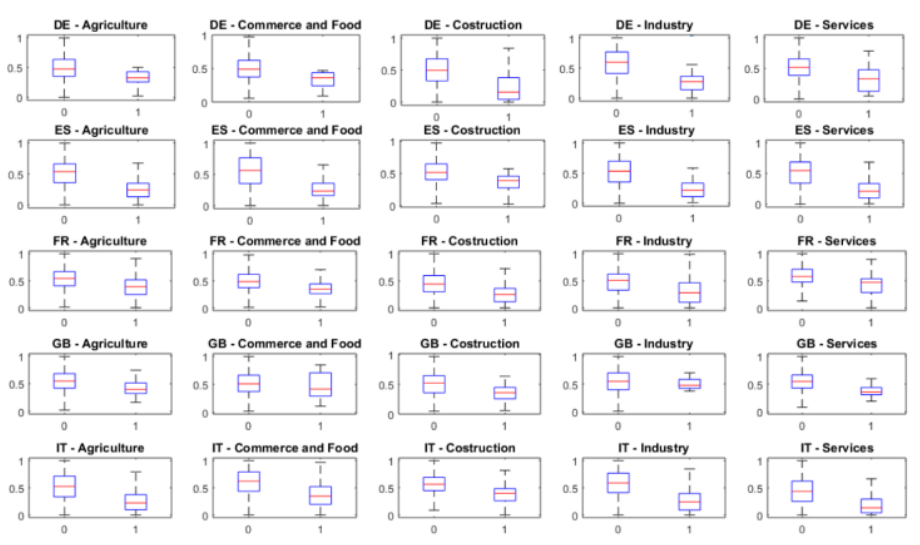

Figure 4. Score model distribution for defaulted and not defaulted companies

Table 12. Distribution metrics for defaulted and not defaulted companies

\begin{tabular}{|c|c|c|c|c|c|c|c|}
\hline \multirow[b]{2}{*}{ Country } & \multirow[b]{2}{*}{ Sector } & \multicolumn{3}{|c|}{ Score percentiles for Default companies } & \multicolumn{3}{|c|}{ Score percentiles for Non Defaulted companies } \\
\hline & & $25^{0}$ & $50^{\circ}$ & $75^{0}$ & $25^{0}$ & $50^{0}$ & $75^{0}$ \\
\hline \multirow[t]{5}{*}{ Germany } & Agriculture & 0.21 & 0.31 & 0.39 & 0.35 & 0.48 & 0.64 \\
\hline & Commerce and food & 0.20 & 0.24 & 0.32 & 0.38 & 0.49 & 0.63 \\
\hline & Construction & 0.03 & 0.19 & 0.34 & 0.33 & 0.50 & 0.68 \\
\hline & Industry & 0.06 & 0.26 & 0.37 & 0.41 & 0.59 & 0.77 \\
\hline & Services & 0.30 & 0.37 & 0.45 & 0.38 & 0.51 & 0.65 \\
\hline \multirow[t]{5}{*}{ Spain } & Agriculture & 0.15 & 0.22 & 0.34 & 0.36 & 0.54 & 0.66 \\
\hline & Commerce and food & 0.18 & 0.25 & 0.35 & 0.35 & 0.56 & 0.78 \\
\hline & Construction & 0.24 & 0.39 & 0.44 & 0.40 & 0.50 & 0.64 \\
\hline & Industry & 0.13 & 0.22 & 0.33 & 0.36 & 0.53 & 0.70 \\
\hline & Services & 0.09 & 0.19 & 0.31 & 0.35 & 0.56 & 0.69 \\
\hline \multirow[t]{5}{*}{ France } & Agriculture & 0.26 & 0.39 & 0.52 & 0.41 & 0.54 & 0.67 \\
\hline & Commerce and food & 0.26 & 0.35 & 0.45 & 0.37 & 0.48 & 0.62 \\
\hline & Construction & 0.13 & 0.25 & 0.38 & 0.30 & 0.44 & 0.60 \\
\hline & Industry & 0.12 & 0.27 & 0.45 & 0.33 & 0.51 & 0.62 \\
\hline & Services & 0.26 & 0.47 & 0.55 & 0.48 & 0.58 & 0.71 \\
\hline \multirow[t]{3}{*}{ Great Britain } & Agriculture & 0.33 & 0.41 & 0.54 & 0.42 & 0.55 & 0.68 \\
\hline & Commerce and food & 0.23 & 0.36 & 0.54 & 0.38 & 0.52 & 0.66 \\
\hline & Construction & 0.21 & 0.32 & 0.46 & 0.36 & 0.52 & 0.63 \\
\hline
\end{tabular}




\begin{tabular}{llllllll}
\hline & Industry & 0.39 & 0.40 & 0.51 & 0.34 & 0.55 & 0.70 \\
& Services & 0.27 & 0.38 & 0.42 & 0.43 & 0.55 & 0.66 \\
\hline Italy & Agriculture & 0.10 & 0.22 & 0.37 & 0.33 & 0.53 & 0.72 \\
& Commerce and food & 0.18 & 0.34 & 0.52 & 0.44 & 0.62 & 0.79 \\
& Construction & 0.26 & 0.40 & 0.49 & 0.45 & 0.56 & 0.69 \\
& Industry & 0.11 & 0.25 & 0.40 & 0.41 & 0.59 & 0.77 \\
& Services & 0.04 & 0.13 & 0.30 & 0.25 & 0.43 & 0.62 \\
\hline
\end{tabular}

The table reports the values of these distribution measures, for both defaulted and not defaulted companies. Overall, not defaulted companies obtained higher scores values than defaulted companies. Most of the models providing good AUC accuracy levels are characterized by $75^{\circ}$ percentile values of defaulted companies lower than $25^{\circ}$ percentile values of not defaulted companies. The other models, except for GB - Industry, are at least characterized by a median value of defaulted companies lower than $25^{\circ}$ percentile values of not defaulted.

By comparing median values reported in Table 12, it is possible to observe some distinction over both Countries and Sectors. Scores values for not defaulted companies range between 0.4 and 0.6, without any specific recurrence of the sector most or least healthy for each Country. Indeed, while Services sector has the best creditworthiness valuation in Spain (0.56), France (0.58) and Great Britain (0.55), the second-best creditworthiness in Germany (0.51) and the worst evaluation in Italy (0.43). Other sectors like Agriculture, reports the top evaluation in one Country only, Germany (0.55), on a par with Great Britain, and medium evaluations in other Countries like France (0.54) or Italy (0.53). By looking at the Country level, still on median values, we can observe a certain nearness of scores for Spain and Great Britain, with values ranging between 0.50 and 0.56 for all sectors. Italy reports the best creditworthiness valuations, except for Services Sector (0.43) which has the worst evaluation overall. Finally, scores in Germany and France range between low values, like 0.44 for Construction in France or 0.49 for Commerce and Food in Germany, to medium values, 0.51 for Services in Germany and 0.54 for Agriculture in France.

Table 12 underlines how the developed algorithm cannot be run as a single model: in fact, the algorithm results vary remarkably for many pairs of Country and Sector. In such regard, it is straightforward that several models have to be developed to capture the specific features belonging to each combination.

\section{Discussion}

The main limitations of this study are the limited availability of financial data in some countries and the time delay from the reporting of financial statement on the national chamber of commerce to the availability of the data through web services. Regarding the first point, although the results obtained by the model turned out to be positive in Germany and Great Britain, we can observe that these countries have greater information gaps than the others. In Great Britain, more than $90 \%$ of companies do not publish information about sales; in Germany, approximately 50\% of the companies report sales while information on the profit and loss per period is made public by approximately $80 \%$ of the companies. Secondly, even if the analysis was carried out during 2020, because of the slowness in disclosing financial information, only data from 2018 were available and used. In such regard, it is clear how using two years old data provides statistics information not coherent with the current financial period.

In this context, it is evident that these technical lacks must be resolved through greater and faster disclosure of information at European level, to standardize not only transparency between countries but also large-scale risk assessments.

Even these limits, the model has proven to be well performing on most of the countries and sectors that have been tested, in particular, in Germany and Spain where the AUC values are concentrated in the 80 - 90 range. For Germany it was obtained the best overall result among all countries in the Commerce and Food sector with an AUC of 92.57; Spain, shows the second-best overall result belonging to the Industry sector, with an AUC of 86.59. In the remaining countries, France, Italy and Great Britain, the results obtained are almost all adequate, with AUC values concentrated between 70 and 80; in this cluster, it is possible to highlight the best results for the Services sector of Great Britain and Italy and for the Industry sector of Italy, where the AUC exceeded the value of 80 . The worst result, however, belongs to Great Britain in the Commerce and Food sector, where the AUC value was 68.80. 


\section{Conclusions}

The credit scoring model that has been developed by the Authors can assess the creditworthiness of a company by using cash flow indicators only, and thanks to the adoption of recently innovative numerical techniques. In particular, the analysis carried out on Spain and Germany turned out to be very accurate providing good AUC results: the goodness of the predictivity, indeed, has markedly varied according to the macro-sectors. The algorithm allows comparing the importance assumed by each cash flow based ratio accurately and provides a strong contribution to the analyst in the business evaluation phase, especially in understanding and judging the liquidity management.

The main weaknesses of this work are the limited availability of financial data in some countries and the time delay from the reporting of financial statement to the availability of the data through web services. It means that a large-scale risk assessment requires - to be useful for the public and the private sectors - greater and faster disclosure of information at European level, and standardization of financial information transparency among countries.

A further extension of this research would be the application of the algorithm under conditions of stress, as the COVID-19 crisis, to understand how much resilient it could demonstrate to be in this "extreme" situation. But to do it, it is necessary to wait for the issue of financial statement data for the financial year 2020 and their diffusion on the databases utilized for this kind of analysis.

\section{Acknowledgments}

The Authors are grateful to modefinance (www.modefinance.com), for the data provided to conduct this analysis. modefinance is a spin-off of the University of Trieste, founded by Prof. Valentino Pediroda and Dr. Mattia Ciprian, and it is the first European fintech rating agency approved by the European Securities and Markets Authority (ESMA).

The views expressed herein are those of the authors and do not necessarily reflect opinions shared by modefinance and Generali Investments Assets Management.

\section{References}

Abdou, H. A. (2009). Genetic programming for credit scoring: The case of Egyptian public sector banks. Expert Systems with Applications, 36(9), 11402-11417. https://doi.org/10.1016/j.eswa.2009.01.076

Almamy, J., Aston, J., \& Ngwa, L. N. (2016). An evaluation of Altman's Z-score using cash flow ratio to predict corporate failure amid the recent financial crisis: Evidence from the UK. Journal of Corporate Finance, 36, 278-285. https://doi.org/10.1016/j.jcorpfin.2015.12.009

Altman, E. I. (1968). Financial ratios, discriminant analysis and the prediction of corporate bankruptcy. The Journal of Finance, 23(4), 589-609. https://doi.org/10.1111/j.1540-6261.1968.tb00843.x

Atiya, A. F. (2001). Bankruptcy prediction for credit risk using neural networks: a survey and new results. IEEE Transactions on Neural Networks, 12(4), 929-935. https://doi.org/10.1109/72.935101

Aziz, A., \& Lawson, G. H. (1989). Cash flow reporting and financial distress models: testing of hypotheses. Financial Management, 18(1), 55-63. https://doi.org/10.2307/3665698

Back, B., Laitinen, T., \& Sere, K. (1996). Neural networks and genetic algorithms for bankruptcy predictions. Expert Systems with Applications, 11(4), 407-413. https://doi.org/10.1016/S0957-4174(96)00055-3

Back, B., Laitinen, T., Sere, K., \& Van Wezel, M. (1996). Choosing bankruptcy predictors using discriminant analysis, logit analysis and genetic algorithms. Turku Centre for Computer Science Technical Report, 40(2), 1-18.

Baixauli, J. S., \& Módica-Milo, A. (2010). The bias of unhealthy SMEs in bankruptcy prediction models. Journal of Small Business and Enterprise Development, 17(1). https://doi.org/10.1108/14626001011019134

Beaver, W. H. (1966). Financial ratios as predictors of failure. Journal of Accounting Research, 4, 71-111. https://doi.org/10.2307/2490171

Bellovary, J. L., Giacomino, D. E., \& Akers, M. D. (2007). A review of bankruptcy prediction studies: 1930 to present. Journal of Financial Education, 33(1), 1-42.

Bhandari, S., \& Johnson-Syder, A. J. (2018). A generic model of predicting probability of success-distress of an organization: a logistic regression analysis. Journal of Applied Business Research, 34(1), 169-182. https://doi.org/10.19030/jabr.v34i1.10107

Bisogno, M., Restaino, M., \& Di Carlo, A. (2018). Forecasting and preventing bankruptcy: A conceptual review.

Published by Sciedu Press $105 \quad$ ISSN 1923-4007 E-ISSN

1923-4015 
African Journal of Business Management, 12(9), 231-242. https://doi.org/10.5897/AJBM2018.8503

Blum, M. (1974). Failing Company Discriminant Analysis. Journal of Accounting Research, 12(1), 1-25. https://doi.org/10.2307/2490525

Casey, C. J., \& Bartczak, N. J. (1984, July-August). Cash flow - it's not the bottom line. Harvard Business Review, (6), 61-66.

Casey, C. J., \& Bartczak, N. J. (1985). Using operating cash flow data to predict financial distress: Some extensions. Journal of Accounting Research, 23(1), 384-401. https://doi.org/10.2307/2490926

Chou, C. H., Hsieh, S. C., \& Qiu, C. J. (2017). Hybrid genetic algorithm and fuzzy clustering for bankruptcy prediction. Applied Soft Computing, 56, 298-316. https://doi.org/10.1016/j.asoc.2017.03.014

Dambolena, I. G., \& Shulman, J. M. (1988). A primary rule for detecting bankruptcy: watch the cash. Financial Analysts Journal, 44(5), 74-78. https://doi.org/10.2469/faj.v44.n5.74

D'Annunzio, N., \& Falavigna, G. (2004). Analysis and forecasting models for default risk. A survey of applied methodologies (No. 200417). Institute for Economic Research on Firms and Growth-Moncalieri (TO). Moncalieri (TO) ITALY: ITALY-NOW-Research Institute on Sustainable Economic Growth.

Deakin, E. B. (1972). A Discriminant Analysis of Predictors of Business Failure. Journal of Accounting Research, 10(1), 167-179. https://doi.org/10.2307/2490225

Fogarty, D. J. (2012). Using genetic algorithms for credit scoring system maintenance functions. International Journal of Artificial Intelligence \& Applications, 3(6), 1. https://doi.org/10.5121/ijaia.2012.3601

Gahlon, J. M., \& Vigeland, R. L. (1988). Early warning signs of bankruptcy using cash flow analysis. The Journal of Commercial Bank Lending, (71), 4-15.

Gentry, J. A., Newbold, P., \& Whitford, D. T. (1985). Predicting bankruptcy: if cash flow's not the bottom line, what is? Financial Analysts Journal, 41(5), 47-56. https://doi.org/10.2469/faj.v41.n5.47

Gilbert, L. R., Menon, K., \& Schwartz, K. B. (1990). Predicting Bankruptcy for Firms in Financial Distress. Journal of Business Finance \& Accounting, 17(1), 161-171. https://doi.org/10.1111/j.1468-5957.1990.tb00555.x

Gombola, M. J., \& Ketz, J. E. (1983). A note on cash flow and classification patterns of financial ratios. The Accounting Review, LVIII(I), 105-114.

Gorzalczany, M. B., \& Rudzinski, F. (2016). A multi-objective genetic optimization for fast, fuzzy rule-based credit classification with balanced accuracy and interpretability. Applied Soft Computing, 40, 206-220. https://doi.org/10.1016/j.asoc.2015.11.037

Helfert, E. A. (1972). Techniques of financial analysis. Illinois: Richard D. Irwin.

Holland, J. H. (1975). Adaptation in natural and artificial systems: an introductory analysis with applications to biology, control, and artificial intelligence. University of Michigan Press.

Huang, K., Zhan, X. L., Chen, F. Q., \& Lü, D. W. (2003). Catalyst design for methane oxidative coupling by using artificial neural network and hybrid genetic algorithm. Chemical Engeneering Science, 58(1), 81-87. https://doi.org/10.1016/S0009-2509(02)00432-3

Jones, S. (2016). A cash flow based model of corporate bankruptcy in Australia. Journal of Applied Management Accounting Research, 14(1), 23.

Jooste, L. (2007). An evaluation of the usefulness of cash flow ratios to predict financial distress. Professional Accountant, 7(1), 1-13. https://doi.org/10.4102/ac.v7i1.2

Khashman, A. (2009). A neural network model for credit risk evaluation. International Journal of Neural Systems, 19(04), 285-294. https://doi.org/10.1142/S0129065709002014

Kim, M. J., \& Kang, D. K. (2010). Ensemble with neural networks for bankruptcy prediction. Expert Systems with Applications, 37(4), 3373-3379. https://doi.org/10.1016/j.eswa.2009.10.012

Laitinen, E. K., \& Suvas, A. (2013). International applicability of corporate failure risk models based on financial statement information: Comparisons across European countries. Journal of Finance \& Economics, 1(3), 1-26. https://doi.org/10.12735/jfe.v1i3p01

Largay III, J. A., \& Stickney, C. P. (1980). Cash flows, ratio analysis and the WT Grant Company bankruptcy. Financial Analysts Journal, 36(4), 51-54. https://doi.org/10.2469/faj.v36.n4.51 
Lee, Y. C. (2007). Application of support vector machines to corporate credit rating prediction. Expert Systems with Applications, 33(1), 67-74. https://doi.org/10.1016/j.eswa.2006.04.018

McCulloch, W. S., \& Pitts, W. (1943). A logical calculus of the ideas immanent in nervous activity. The Bulletin of Mathematical Biophysics, 5(4), 115-133. https://doi.org/10.1007/BF02478259

Mensah, Y. M. (1983). The differential bankruptcy predictive ability of specific price level adjustments: some empirical evidence. The Accounting Review, LVIII(2), 228-246.

Min, J. H., \& Lee, Y. C. (2005). Bankruptcy prediction using support vector machine with optimal choice of kernel function parameters. Expert Systems with Applications, 28(4), 603-614. https://doi.org/10.1016/j.eswa.2004.12.008

Moscatelli, M., Parlapiano, F., Narizzano, S., \& Viggiano, G. (2020). Corporate default forecasting with machine learning. Expert Systems with Applications, 161, 113567. https://doi.org/10.1016/j.eswa.2020.113567

Nanni, L., \& Lumini, A. (2009). An experimental comparison of ensemble of classifiers for bankruptcy prediction and credit scoring. Expert Systems with Applications, 36(2), 3028-3033. https://doi.org/10.1016/j.eswa.2008.01.018

Norton, C. L., \& Smith, R. E. (1979). A Comparison of General Price Level and Historical Cost Financial Statements in the Prediction of Bankruptcy. The Accounting Review, 54(1), 72-87.

Satchel, S., \& Xia, W. (2006). Analytic Models of the ROC Curve: Applications to Credit Rating Model Validation (No. 181). Sydney: Quantitative Finance Research Centre, University of Technology. https://doi.org/10.2139/ssrn.966131

Sharma, D. S. (2001). The role of cash flow information in predicting corporate failure: The state of the literature. Managerial Finance, 27(4), 3-28. https://doi.org/10.1108/03074350110767114

Shin, K. S., Lee, T. S., \& Kim, H. J. (2005). An application of support vector machines in bankruptcy prediction model. Expert Systems with Applications, 28(1), 127-135. https://doi.org/10.1016/j.eswa.2004.08.009

Sun, J., \& Li, H. (2008). Data mining method for listed companies' financial distress prediction. Knowledge-Based Systems, 21(1), 1-5. https://doi.org/10.1016/j.knosys.2006.11.003

Sun, J., Jia, M. Y., \& Li, H. (2011). AdaBoost ensemble for financial distress prediction: an empirical comparison with data from Chinese listed companies. Expert Systems with Applications, 38(8), 9305-9312. https://doi.org/10.1016/j.eswa.2011.01.042

Tam, K. Y., \& Kiang, M. Y. (1992). Managerial applications of neural networks: the case of bank failure predictions. Management Science, 38(7), 926-947. https://doi.org/10.1287/mnsc.38.7.926

Tsai, C. F., \& Wu, J. W. (2008). Using neural network ensembles for bankruptcy prediction and credit scoring. Expert Systems with Applications, 34(4), 2639-2649. https://doi.org/10.1016/j.eswa.2007.05.019

Veronica, M. S., Ida, I., \& Winata, V. T. (2020). Using cash flow ratios to establish a manufacturing bankruptcy prediction model. Jurnal Manajemen Indonesia, 20(2), 115-123. https://doi.org/10.25124/jmi.v20i2.3198

Viscione, J. A. (1985). Assessing financial distress. The Journal of Commercial Bank Lending, 67(11), 39-55.

Vlachos, D., \& Tolias, Y. A. (2003). Neuro-fuzzy modeling in bankruptcy prediction. Yugoslav Journal of Operations Research, 13(2), 165-174. https://doi.org/10.2298/YJOR0302165V

West, D., Dellana, S., \& Qian, J. (2005). Neural network ensemble strategies for financial decision applications. Computers \& Operations Research, 32(10), 2543-2559. https://doi.org/10.1016/j.cor.2004.03.017

Wilson, R. L., \& Sharda, R. (1994). Bankruptcy prediction using neural networks. Decision Support Systems, 11(5), 545-557. https://doi.org/10.1016/0167-9236(94)90024-8

Yang, Z. R., Platt, M. B., \& Platt, H. D. (1999). Probabilistic neural networks in bankruptcy prediction. Journal of Business Research, 44(2), 67-74. https://doi.org/10.1016/S0148-2963(97)00242-7

Zadeh, L. A. (1965). Fuzzy sets. Information and Control, 8(3), 338-353. https://doi.org/10.1016/S0019-9958(65)90241-X

Zięba, M., Tomczak, S. K., \& Tomczak, J. M. (2016). Ensemble boosted trees with synthetic features generation in application to bankruptcy prediction. Expert Systems with Applications, 58, 93-101. 


\section{Note}

Note 1. Let's suppose to compare two companies. For the first company only the leverage ratio is available while for the second only the current ratio. Furthermore, let's suppose that the leverage value of the first company is equal to 4 while the current ratio of the second company is equal to 2. Ceteris paribus, it is possible to affirm that the second company is characterized by a better creditworthiness than the former. The use of mere raw data, however, does not allow stating either how positive the situation of the second company is or how negative the situation of the first is.

In this context, it is necessary to adopt automatic numerical methods capable of converting the leverage value equal to 4 and the current ratio value equal to 2 into new values belonging to the same scale and, therefore, homogeneous. Assuming to observe the above example through the eyes of a financial analyst, the leverage and current ratio values could be converted, respectively, into 0.35 and 0.75 .

\section{Copyrights}

Copyright for this article is retained by the author(s), with first publication rights granted to the journal.

This is an open-access article distributed under the terms and conditions of the Creative Commons Attribution license (http://creativecommons.org/licenses/by/4.0/). 